\title{
ECLÉTICA A
}

www.scielo.br/eq

Volume 30, número 1, 2005

\section{Synthetic model of a new deoxybenzoin derivative from Deguelia hatschbachii A.M.G. Azevedo}

\author{
A. F. Magalhães ${ }^{1 *}$, E. G. Magalhães ${ }^{1}$ G. Trazzi $^{1}$ V. R. de S. Moraes ${ }^{2}$ \\ ${ }^{1}$ Departamento de Química Orgânica- Instituto de Química- UNICAMP, C.P. 6154, \\ 13081-970- Campinas- SP-Brasil, \\ ${ }^{2}$ Departamento de Química- Centro de Ciências Exatas e Tecnologia- UFS- \\ 49100-000- São Cristóvão- SE- Brasil \\ *e-mail: aderbal@iqm.unicamp.br
}

\begin{abstract}
In this paper we describe the synthesis of 2',4'-dimethoxy-8-(propyl-2-one)-deoxybenzoin, a new compound employed as a model for the comparison with the respective spectral data for 6 ',4dihydroxy-3'-(3,3- dimethylallyl)-2",2"-dimethylchromene(5",6":5',4')-2'-methoxy-8-(propyl-2-one) deoxybenzoin, recently isolated from Deguelia hatschbachii A.M.G. Azevedo. Both compounds have a "propyl-2-one" group attached to C-8 of the deoxybenzoin skeleton, for which there is no precedent in the literature. The Friedel-Crafts reaction of 1,3-dimethoxybenzene with phenylacetyl chloride furnished 2',4'-dimethoxydeoxybenzoin, that after reaction with allyl bromide gave 2',4'-dimethoxy-8-(allyl)deoxybenzoin. Wacker oxidation gave the desired model compound in $15 \%$ overall yield. The corresponding spectral data reinforced the structure previously determined for the natural product.
\end{abstract}

Keywords: Deguelia hatschbachii; Leguminosae; deoxybenzoin.

\section{Introduction}

The chemical investigation of the dichloromethane and petrol extracts from the roots of Deguelia hatschbachii A. M. G. Azevedo furnished a new deoxybenzoin derivative 1 (Figure 1); its structure was determined by spectral analysis (MS, ${ }^{1} \mathrm{H}$ and ${ }^{13} \mathrm{C}$ NMR) [1]. Previously only six natural deoxybenzoin 3a-3f derivatives have been isolated and five of these are a-methylated (Figure 2) [2-8].

The synthesis of a-methyl deoxybenzoins is achieved by methylation of deoxybenzoin derivatives [6]. In addition, deoxybenzoins are useful starting materials for the synthesis of several natural products, such as isoflavanones, stilbenes and others [9].

Moreover, it might be mentioned that the reactivity of deoxybenzoin derivatives with regard to a-alkylation remains little explored; and until now has been restricted to the a-methylation reaction $[6,9]$.

In this paper, we describe our results on the synthesis of the model compound 2 (Figure 1), according to Scheme 1, in order to compare its spectral data with those furnished by the natural product $\mathbf{1}$, thus reinforcing its molecular structure determination [1]. 


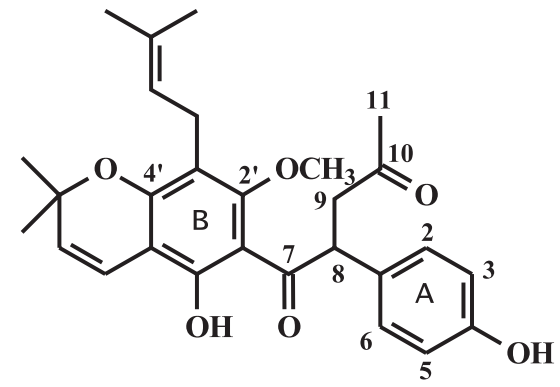

(1)

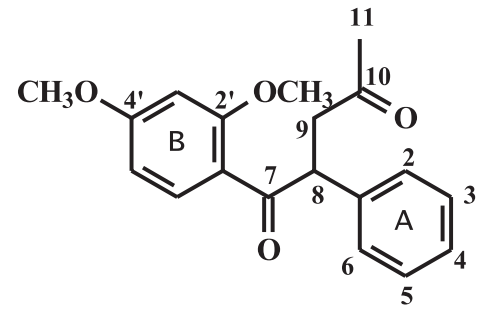

(2)

Figure 1. Natural (1) and synthetic (2) deoxybenzoin derivatives

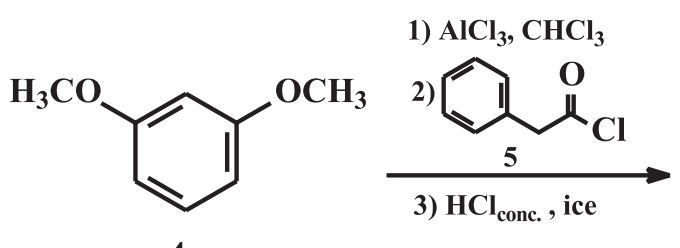

4<smiles>C#CCC(C(=O)c1ccc(OC)cc1OC)c1ccccc1</smiles><smiles>COc1ccc(C(=O)Cc2ccccc2)c(OC)c1</smiles>

Figure 2. Natural deoxybenzoin derivatives<smiles>COc1cccc(OC)c1</smiles><smiles>C=CCC(C(=O)c1ccc(OC)cc1OC)c1ccccc1</smiles><smiles>COc1ccc(C(=O)C(CC(C)=O)c2ccccc2)c(OC)c1</smiles>

Scheme 1 
Materials and methods

${ }^{1} \mathrm{H}$ NMR (300 and $500 \mathrm{MHz}$ ), ${ }^{13} \mathrm{C}$ NMR (75 and $125 \mathrm{MHz}$ ), ${ }^{1} \mathrm{H}_{-}{ }^{13} \mathrm{C}$ HETCOR ${ }^{1} \mathrm{~J}_{\mathrm{CH}}$ and ${ }^{1} \mathrm{H}_{-}{ }^{13} \mathrm{C}$ COLOC ${ }^{n} J_{C H}(n=2$ and 3) spectra were recorded using BRUKERAC 300/P, GEMINI 2000 (VARIAN), GEMINI 300 BB (VARIAN) and INOVA 500 (VARIAN) spectrometer, in $\mathrm{CDCl}_{3}$ as solvent; with TMS as internal standard. Chemical shifts (d) are in ppm and the coupling constants $(J)$ in Hertz $(\mathrm{Hz})$.

EIMS $70 \mathrm{eV}$, direct probe. HREIMS was performed in a VG Auto Spec-Fisions Instrument by using an eletron ionization technique at $70 \mathrm{eV}$ (linked scan at $8 \mathrm{KeV}$ collisions with Helium).

\section{Reagents}

The already known synthetic intermediates 4 and 5 were prepared respectively from resorcinol and phenylacetic acid as described. Both of them were characterized through the respective spectral data.

Synthesis of 2',4'-dimethoxydeoxybenzoin 6

To a three-necked flask (50 mL) equipped with a condenser, an addition funnel, an $\mathrm{HCl}$ trap and a stopper with $\mathrm{N}_{2(\mathrm{~g})}$ flow, $\mathrm{AlCl}_{3}$ (2.75 g, $0.021 \mathrm{~mol})$ and dry $\mathrm{CHCl}_{3}(15 \mathrm{~mL})$ were added. The flask was then cooled with an ice bath, and a solution of phenylacetyl chloride $(2.75 \mathrm{~mL})$ in $\mathrm{CHCl}_{3}(5.0 \mathrm{~mL})$ slowly added via the addition funnel, until all the solid $\mathrm{AlCl}_{3}$ had dissolved. A solution of 1,3-dimethoxybenzene (2.0 g, 14.5 $\mathrm{mmol})$ in $\mathrm{CHCl}_{3}(5.0 \mathrm{~mL})$ was then added dropwise through the addition funnel, to avoid excessive evolution of gaseous $\mathrm{HCl}$. The ice bath was then removed, and the mixture was left standing at room temperature over 1 hour. The reaction was poured into a beacker containing ice (10 g) and concentrated $\mathrm{HCl}(5.0 \mathrm{~mL})$, and stirred over $15 \mathrm{~min}$. The organic material was extracted with diethyl ether ( $2 \times 50 \mathrm{~mL}$ ), dried over $\mathrm{Na}_{2} \mathrm{SO}_{4}$, filtered and concentrated. Flash column chromatography (eluant hexane: $\mathrm{CH}_{2} \mathrm{Cl}_{2} 1: 1 \mathrm{v} / \mathrm{v}$ ) of the crude product afforded the desired 2',4'dimethoxydeoxybenzoin 6 (1.65 g, $44 \%)$ as a viscous yellowish oil. ${ }^{1} \mathrm{H}$ NMR spectral data (300 $\mathrm{MHz}, \mathrm{CDCl}_{3} / \mathrm{TMS}$ ): Table $1 .{ }^{13} \mathrm{C}$ NMR spectral data (75 MHz, $\mathrm{CDCl}_{3}$ ): Table 2. EIMS (probe) $70 \mathrm{eV}, \mathrm{m} /$ z (rel. int.): Figure 3.
Synthesis of 2',4'-dimethoxy-8-allyl-deoxybenzoin 7

In a dry two-necked round bottomed flask ( $25 \mathrm{~mL}$ ), equipped with a magnetic stirrer, a moisture trap and a stopper, was added a solution of $\mathbf{6}$ (80.0 $\mathrm{mg}, 0.31 \mathrm{mmol})$ in anhydrous THF $(10 \mathrm{~mL})$ and $\mathrm{NaH}$ (37.5 mg, $1.55 \mathrm{mmol}$ ). The reaction was left under stirring for $3 \mathrm{~h}$. A solution of allyl bromide ( $47.0 \mathrm{~mL}$, $0.55 \mathrm{mmol})$ in anhydrous THF $(5.0 \mathrm{~mL})$ was then slowly added during $1.5 \mathrm{~h}$. The reaction was stirred for a further $2 \mathrm{~h}$. After this period, the reaction mixture was poured into a beacker containing ice, and neutralized with $\mathrm{HCl} 10 \%$ (v/v). The organic material was extracted with diethyl ether ( 2 x $25 \mathrm{~mL})$, dried over $\mathrm{Na}_{2} \mathrm{SO}_{4}$, filtered and concentrated. The crude product was purified by preparative thin layer chromatography (eluant hexane:diethyl ether 1:1 v/ v), furnishing the allylated deoxybenzoin 7 (42.0 mg, $0.14 \mathrm{mmol}$ ) as a yellowish oil in a yield of $45 \% .{ }^{1} \mathrm{H}$ NMR spectral data (500 MHz, $\mathrm{CDCl}_{3} / \mathrm{TMS}$ ): Table 1. ${ }^{13} \mathrm{C}$ NMR spectral data (125 MHz, $\mathrm{CDCl}_{3}$ ): Table 2. EIMS (probe) $70 \mathrm{eV}, \mathrm{m} / \mathrm{z}$ (rel. int.): Figure 3.

Synthesis of 2',4'-dimethoxy-8-(propyl-2-one)deoxybenzoin 2 [10]

To a round bottomed flask ( $25 \mathrm{~mL})$, were added a mixture of DMF: $\mathrm{H}_{2} \mathrm{O}(7: 1 \mathrm{v} / \mathrm{v}, 7.0 \mathrm{~mL}), \mathrm{PdCl}_{2}$ (2.5 mg, $0.014 \mathrm{mmol}$ ) and $\mathrm{CuCl}$ 90\% (15 mg, 0.14 mmol). A rubber septum was coupled with a ballon filled with $\mathrm{O}_{2(\mathrm{~g})}$ and the reaction was left stirring at room temperature for $1 \mathrm{~h}$. A solution of 7 (42 mg, $0.14 \mathrm{mmol})$ in DMF: $\mathrm{H}_{2} \mathrm{O}(7: 1 \mathrm{v} / \mathrm{v}, 3.0 \mathrm{~mL})$ was slowly added over $15 \mathrm{~min}$, and the reaction was left under stirring overnight. After this period, the crude product was poured into a beacker containing ice (10 g) and $\mathrm{HCl} \mathrm{10 \%} \mathrm{v/v} \mathrm{(10} \mathrm{mL),} \mathrm{and} \mathrm{stirred} \mathrm{for} 15 \mathrm{~min}$. The organic material was exhaustively extracted with dimethyl ether ( 5 x $25 \mathrm{~mL}$ ), and the separated organic layer was washed with saturated $\mathrm{NaHCO}_{3}(25 \mathrm{~mL})$ and $\mathrm{NaCl}$ solution (25 mL), dried over $\mathrm{Na}_{2} \mathrm{SO}_{4}$ and then concentrated. The crude product was submitted to continuous preparative thin layer chromatography (hexane:diethyl ether $1: 2 \mathrm{v} / \mathrm{v}, 2 \mathrm{~h}$ at $0^{\circ} \mathrm{C}$ ) affording the desired deoxybenzoin 2 ( $33.7 \mathrm{mg}, 0.11 \mathrm{mmol}$ ) as a viscous yellowish oil in a yield of 79\%. ${ }^{1} \mathrm{H}$ NMR spectral data (500 MHz, $\mathrm{CDCl}_{3} / \mathrm{TMS}$ ): Table $1 .{ }^{13} \mathrm{C}$ NMR spectral data (125 MHz, $\left.\mathrm{CDCl}_{3}\right)$ : Table 2 . HREIMS $\mathrm{m} / \mathrm{z}$ : found $312.1362[\mathrm{M}]^{+}\left(\mathrm{C}_{19} \mathrm{H}_{20} \mathrm{O}_{4}\right.$ requires 312.1361), Figure 3. 


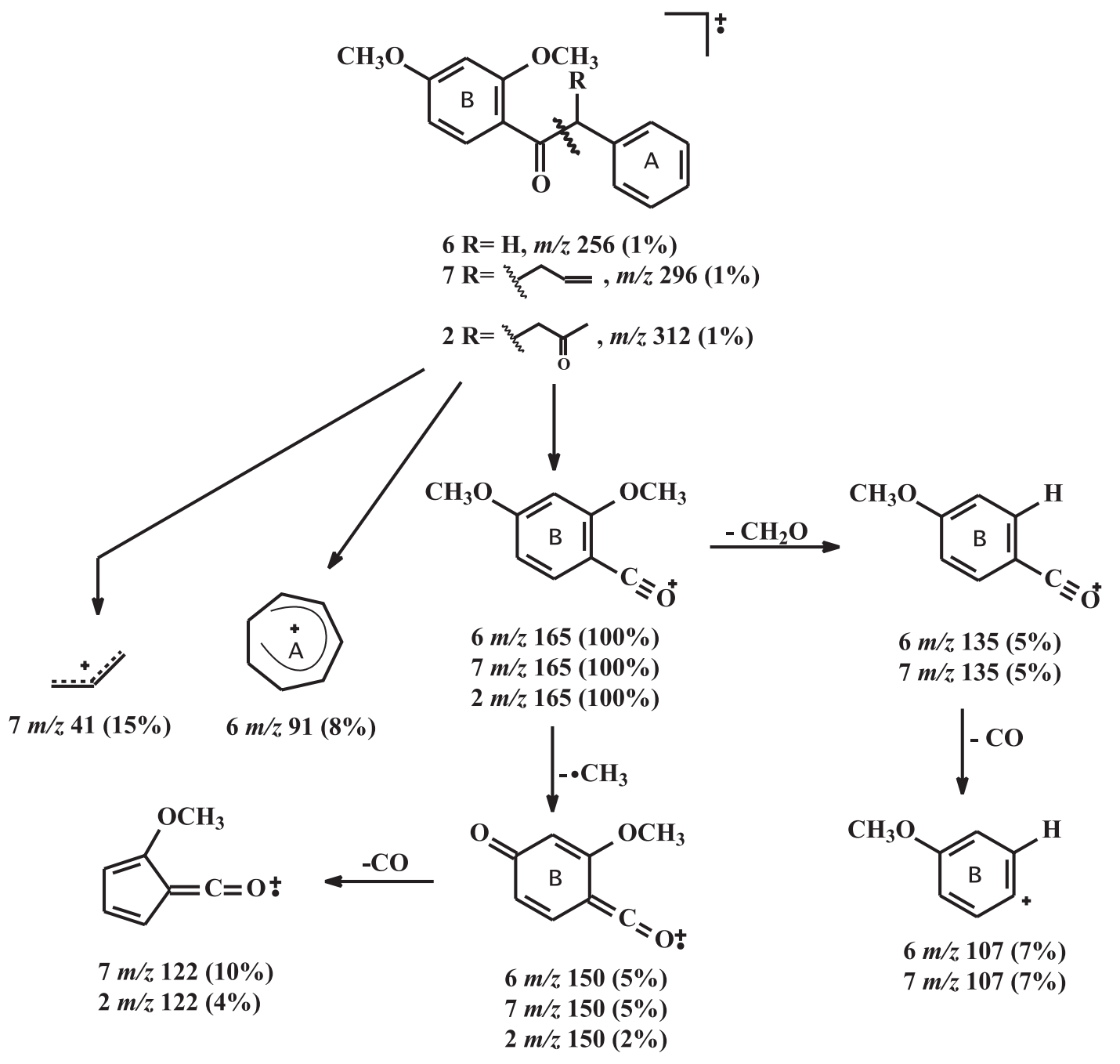

Figure 3. Fragmentation pathway of deoxybenzoins 2, 6 and 7

\section{Results and Discussion}

By analogy with the synthesis of some deoxybenzoins [9], the Friedel-Crafts acylation (Scheme 1) of 1,3-dimethoxybenzene 4 with phenylacetyl chloride $\mathbf{5}$ gave 2',4'dimethoxydeoxybenzoin $\mathbf{6}$ as expected and confirmed by ${ }^{1} \mathrm{H}$ and ${ }^{13} \mathrm{C}$ NMR (Tables 1 and 2) and
MS (Figure 3) data, where the deoxybenzoin skeleton is evidenced by the absorptions at $d_{H} 4.12$ (s, 2H), $d_{C} 49.6\left(\mathrm{CH}_{2}\right)$ and a base peak at $\mathrm{m} / \mathrm{z} 165$ (100\%) respectively. According to the MS spectral data of many other synthetic deoxybenzoin derivatives [7] the base peak corresponds to the cleavage of C-7/C-8 bond, the resulting fragments (a cation and a radical) are both stable. 
Table 1. ${ }^{1} \mathrm{H}$ (300* and $500 \mathrm{MHz}$ ) NMR spectral data for compounds 2, 6 and 7. The chemical shifts are in $\delta$ (ppm). Coupling constants ( $)$ in $\mathrm{Hz}$ and multiplicity are described in parentheses.

\begin{tabular}{|c|c|c|c|}
\hline Hydrogen & $\begin{array}{c}2 \\
\delta_{\mathrm{H}} \\
\end{array}$ & $\begin{array}{l}6^{*} \\
\delta_{H} \\
\end{array}$ & $\begin{array}{c}7 \\
\delta_{\mathbf{H}} \\
\end{array}$ \\
\hline 1 & - & - & - \\
\hline 2 and 6 & $7.09(\mathrm{~m})$ & $7.12(\mathrm{~m})$ & $7.10(\mathrm{~m})$ \\
\hline 3 and 5 & $7.09(\mathrm{~m})$ & $7.12(\mathrm{~m})$ & $7.10(\mathrm{~m})$ \\
\hline 4 & $7.09(\mathrm{~m})$ & $7.12(\mathrm{~m})$ & $7.10(\mathrm{~m})$ \\
\hline 7 & - & - & - \\
\hline 8 & $5.06(d d, 9.6,4.5)$ & $4.12(s)$ & $4.57(\mathrm{~m})$ \\
\hline \multirow[t]{2}{*}{9} & $3.36(d d, 17.4,9.6)$ & - & $2.35(\mathrm{~m})$ \\
\hline & $2.47(d d, 17.4,4.5)$ & & $2.85(\mathrm{~m})$ \\
\hline 10 & - & - & $5.65(m)$ \\
\hline \multirow[t]{2}{*}{11} & $2.08(s)$ & - & $4.95(d d, 16.8,1.0)$ \\
\hline & & & $4.85(d d, 10.3,1.0)$ \\
\hline 1 ' & - & - & - \\
\hline $2^{\prime}$ & - & - & - \\
\hline 3 , & $6.21(d, 2.0)$ & $6.30(d, 2.2)$ & $6.30(d, 2.2)$ \\
\hline 4 ' & - & - & - \\
\hline 5 & $6.36(d d, 8.6,2.0)$ & $6.40(d d, 8.8,2.2)$ & $6.40(d d, 8.8,2.2)$ \\
\hline 6 & $7.69(d, 8.6)$ & $7.67(d, 8.8)$ & $7.67(d, 8.8)$ \\
\hline $2{ }^{\prime}-\mathrm{OCH}_{3}$ & $3.72(s)$ & $3.77(s)$ & $3.77(s)$ \\
\hline $4^{\prime}-\mathrm{OCH}_{3}$ & $3.74(s)$ & $3.82(s)$ & $3.82(s)$ \\
\hline
\end{tabular}

Table 2. ${ }^{13} \mathrm{C}$ (75* and $125 \mathrm{MHz}$ ) NMR spectral data for compounds 2, 6 and 7.

\begin{tabular}{cccc}
\hline & $\mathbf{2}$ & $\mathbf{6}^{*}$ & $\mathbf{7}$ \\
Carbon & $\delta_{\mathbf{C}}$ & $\delta_{\mathbf{C}}$ & $\delta_{\mathbf{C}}$ \\
\hline 1 & 139.7 & 135.5 & 139.9 \\
2 and 6 & 128.1 & 129.2 & 128.5 \\
3 and 5 & 128.0 & 127.7 & 128.0 \\
4 & 126.1 & 125.9 & 126.3 \\
7 & 196.4 & 194.8 & 197.8 \\
8 & 52.2 & 49.6 & 57.0 \\
9 & 47.8 & - & 38.6 \\
10 & 203.9 & - & 136.7 \\
11 & 29.7 & - & 115.9 \\
$1 '$ & 120.3 & 121.0 & 121.0 \\
2 & 159.7 & 160.0 & 163.7 \\
$3 '$ & 97.9 & 98.0 & 98.1 \\
4 & 163.8 & 164.0 & 159.6 \\
$5^{\prime}$ & 104.8 & 104.7 & 104.9 \\
6 & 133.3 & 127.3 & 133.2 \\
2' $^{\prime}-\mathrm{OCH}_{3}$ & 54.7 & 55.3 & 54.9 \\
4'-OCH & 54.6 & 55.3 & 54.8 \\
\hline
\end{tabular}


The alkylation reaction with allyl bromide in THF and NaH afforded 2',4'-dimethoxy-8-allyldeoxybenzoin 7 , a new deoxybenzoin derivative, which was confirmed from the corresponding spectral data, 1D- and 2D- NMR (Tables 1, 2 and 3) and MS (Figure 3).

Compound 7 revealed the presence of one multiplet at $\mathrm{d} 4.57(1 \mathrm{H})$, three multiplets at d 5.65
$(1 \mathrm{H}), 2.85(1 \mathrm{H})$ and $2.35(1 \mathrm{H})$, and two one-proton doublet of doublets at d $4.95(J=16.8,1.0 \mathrm{~Hz})$ and $4.85(\mathrm{~J}=10.3,1.0 \mathrm{~Hz})$ in the ${ }^{1} \mathrm{HNMR}$ spectrum consistent with the presence of an allyl group on C8 , which was also confirmed in the ${ }^{13} \mathrm{C}$ NMR spectrum and DEPT $\left(90^{\circ}\right.$ and $\left.135^{\circ}\right)$ experiments by the signals at $\mathrm{d} 57.0(\mathrm{CH}, \mathrm{C}-8), 38.6\left(\mathrm{CH}_{2}, \mathrm{C}-9\right)$, 136.7 (CH, C-10) and $115.9\left(\mathrm{CH}_{2}, \mathrm{C}-11\right)$.

Table 3. Observed correlation in gHMBC (long-range C-H) spectra ( $\mathrm{CDCl}_{3}, 11$ Tesla) of 7

\begin{tabular}{cc}
\hline Hydrogen $(\delta)$ & $\mathbf{C}\left(\delta,{ }^{n} \boldsymbol{J}\right)$ \\
\hline 2 to $6(7.10)$ & $1(139.9), 2$ to $6(126.3,128.5,128.0)$ \\
$8(4.57)$ & $7(197.8), 1(139.9), 10(136.7), 2 / 6(128.5), 9(38.6)$ \\
$9(2.35,2.85)$ & $7(197.8), 1(139.9), 10(136.7), 11(115.9), 8(57.0)$ \\
$10(5.65)$ & $9(38.6)$ \\
$11(4.95,4.85)$ & $9(38.6)$ \\
$6 '(7.67)$ & $7(197.8), 4^{\prime}(159.6), 2^{\prime}(163.7)$ \\
$5^{\prime}(6.40)$ & $1^{\prime}(121.0), 3^{\prime}(98.1)$ \\
$3^{\prime}(6.30)$ & $2^{\prime}(163.7), 4^{\prime}(159.6), 1^{\prime}(121.0), 5$ \\
$2^{\prime}-\mathrm{OCH}_{3}(3.77)$ & $2^{\prime}(163.7)$ \\
$4^{\prime}-\mathrm{OCH}_{3}(3.82)$ & $4^{\prime}(159.6)$ \\
\hline
\end{tabular}

The final step involved the oxidation of the a-allyldeoxybenzoin 7 with $\mathrm{CuCl}$ and $\mathrm{PdCl}_{2}$ resulting in the formation of the target compound $\mathbf{2}$.

The HREIMS revealed a molecular ion $[\mathrm{M}]^{+}$ of $\mathrm{m} / \mathrm{z} 312.1362$, corresponding to $\mathrm{C}_{19} \mathrm{H}_{20} \mathrm{O}_{4}$ (required $\mathrm{M}^{+}$312.1361). The ${ }^{1} \mathrm{H}$ NMR spectrum showed three doublet of doublets at d $5.06(J=9.6$, $4.5 \mathrm{~Hz}), 3.36(J=17.4,9.6 \mathrm{~Hz})$ and $2.47(J=17.4$, $4.5 \mathrm{~Hz}$ ), and a singlet at d $2.08(3 \mathrm{H})$ respectively, assignable to an ABX system and an acetyl methyl group. This was confirmed by the presence of a methyl carbon signal at d 29.7 and a carbonyl carbon signal at d 203.9, corresponding to an alkyl ketone, in the ${ }^{13} \mathrm{C}$ NMR spectrum. Other signals in the ${ }^{13} \mathrm{C}$ NMR spectrum were compatible and DEPT $\left(90^{\circ}\right.$ and $\left.135^{\circ}\right)$ experiments showed the presence of three $\mathrm{CH}_{3}$, one $\mathrm{CH}_{2}$, nine $\mathrm{CH}$ and six quaternary carbons.

All hydrogen and carbon chemical shifts were confirmed by 2D-NMR experiments such as gCOSY, HSQC and gHMBC data (Table 4).

The comparison of the NMR spectral data furnished by the model compound 2 and the natural product 1 reinforced the structural assigment of the natural product (Table 5).

Table 4. Observed correlation in gHMBC (long-range C-H) spectra $\left(\mathrm{CDCl}_{3}, 11\right.$ Tesla) of 2.

\begin{tabular}{cc}
\hline Hydrogen $(\delta)$ & $\mathbf{C}\left(\delta,{ }^{n} \boldsymbol{J}\right)$ \\
\hline $6^{\prime}(7.69)$ & $8(196.4), 4^{\prime}(163.8), 2^{\prime}(159.7)$ \\
2 to 6 (7.09) & $1(139.7), 2 / 6(128.1), 3 / 5(128.0), 4(126.1), 7(52.2)$ \\
$5^{\prime}(6.36)$ & $1^{\prime}(120.3), 3^{\prime}(97.9)$ \\
$3^{\prime}(6.21)$ & $4^{\prime}(163.8), 2^{\prime}(159.7), 1^{\prime}(120.3), 5^{\prime}(104.8)$ \\
$7(5.06)$ & $10(203.9), 8(196.4), 1(139.7), 2 / 6(128.1), 3 / 5$ \\
& $(128.0), 7(52.2), 9(47.8)$ \\
$2^{\prime}-\mathrm{OCH}_{3}(3.72)$ & $2^{\prime}(159.7)$ \\
$4^{\prime}-\mathrm{OCH}_{3}(3.74)$ & $4^{\prime}(163.8)$ \\
$9{ }^{(3.36 \text { and } 2.47)}$ & $10(203.9), 8(196.4), 1(139.7), 7(52.2)$ \\
$11(2.08)$ & $10(203.9), 9(47.8)$ \\
\hline
\end{tabular}


Table 5. Comparative analysis of the ${ }^{1} \mathrm{H}(500 \mathrm{MHz})$ and ${ }^{13} \mathrm{C}(125 \mathrm{MHz}) \mathrm{NMR}$ spectral data for compounds $\mathbf{1}^{1}$ and $\mathbf{2}$, in $\mathrm{CCl}_{4}(*)$ or $\mathrm{CDCl}_{3}{ }^{(*)}$ and TMS as internal standard. The chemical shifts are in d (ppm). Coupling constants $(J)$ in $\mathrm{Hz}$ and multiplicity are described in parentheses.

\begin{tabular}{ccccc}
\hline $\mathbf{H}$ & $\mathbf{2}\left(\delta_{\mathbf{H}}\right)^{*}$ & $\mathbf{1}\left(\delta_{\mathbf{H}}\right)^{\#}$ & $\mathbf{2}\left(\delta_{\mathbf{C}}\right)^{*}$ & $\mathbf{1}\left(\delta_{\mathbf{C}}\right)^{\#}$ \\
\hline 8 & $5.06(d d, 9.6,4.5)$ & $5.34(d d, 10.5,4.0)$ & 52.2 & 49.7 \\
9 & $3.36(d d, 17.4,9.6)$ & $3.50(d d, 17.8,10.5)$ & 47.8 & 47.7 \\
& $2.47(d d, 17.4,4.5)$ & $2.57(d d, 17.8,4.0)$ & & \\
10 & - & - & 203.9 & 207.6 \\
11 & $2.08(s)$ & $2.12(s)$ & 29.7 & 30.0 \\
\hline
\end{tabular}

\section{Conclusions}

The synthetic route was useful for the preparation of the desired model compound 2. It must be mentioned that the new deoxybenzoin derivatives 2 and $\mathbf{7}$ were prepared through a new route.

The spectral data furnished by $\mathbf{2}$ gave a strong enlighentment about the studied system, and is coherent, confirming the unusual structure previously given for the natural product 1 .

The MS and ${ }^{13} \mathrm{C}$ NMR spectral data of 2',4'dimethoxydeoxybenzoin [6] are now given for the first time.

A. F. Magalhães, E. G. Magalhães, G. Trazzi, V. R. de S. Moraes. Modelo sintético de um novo derivado de desoxibenzoína de Deguelia hatschbachii A.M.G. Azevedo.

Resumo: Neste trabalho descrevemos a síntese de 2',4'-dimetoxi-8-(propil-2-ona) desoxibenzoína, um composto novo, a fim de usá-la como um modelo na comparação dos respectivos dados espectroscópicos de 6',4dihidroxi-3'-(3,3-dimetilalil)-2",2"-dimetilcromeno(5",6":5',4')-2'-metoxi-8-(propil-2-ona) desoxibenzoína, recentemente isolada de Deguelia hatschbachii A.M.G. Azevedo. Os dois compostos tem um grupo "propil-2ona” ligado no carbono C-8 do esqueleto desoxibenzoínico, que não mostra precedentes na literatura. A reação de Friedel-Crafts do 1,3-dimetoxibenzeno com o cloreto de fenilacetila forneceu 2',4'-dimetoxidesoxibenzoína, que ao reagir com brometo de alila forneceu 2',4'-dimetoxi-8-(alil)-desoxibenzoína. A oxidação de Wacker forneceu o composto modelo desejado com rendimento total de $15 \%$. Os dados espectrais obtidos do produto reforçaram a estrutura previamente determinada para o produto natural.

Palavras-chave: Deguelia hatschbachii; Leguminosae; desoxibenzoína.

\section{References}

[1] A. F. Magalhães, A. M. G. A. Tozzi, E. G. Magalhães, V. R. S. Moraes, Phytochem. 57(1) (2001), 77.

[2] F. E. King, T. J. King, A. J. Warwick, J. Chem. Soc. 96 (1952), 1920.

[3] B. C. B. Bezuidenhoudt, E. V. Brandt, D. G. Roux, P. H. Van Rooyen, J. Chem. Soc. Perkin Trans I (1980), 2179.

[4] B. C. B. Bezuidenhoudt, E. V. Brandt, D. G. Roux, J. Chem. Soc.Perkin Trans I (1981), 263.

[5] E. Wong, The isoflavonoids . In: J. B. Harborne, T. J. Mabry,
H. Mabry, The Flavonoids. New York: Chapman and Hall,1975. [6] A. C. Jain, P. Paliwal, Indian J. Chem. 27B (1988), 985. [7] A. Salakka, K. Wähälä, J. Chem. Soc. Perkin Trans. I (1999), 2601.

$\left.{ }^{8}\right]$ F. Kiuchi, X. Chen, Y. Tsuda, Heteroc. 31(4) (1990), 629. [9] N. Devi, N. Jain, H. G. Krishnamurty, Indian J. Chem. 32B (1993), 874.

[10] F. A. S. Coelho, G. Diaz, Tetrahedron 58 (2002), 1647. (Footnotes) 